\title{
Deltamethrin'in Carassius gibelio (Bloch, 1782)'nun Solungaç, Karaciğer ve Bağırsak Dokuları Üzerine Histopatolojik Etkilerinin Araştırılması
}

\author{
Neriman GEY ${ }^{1 *}$, Yusuf ERSAN ${ }^{2}$ \\ ${ }^{1}$ Kafkas Üniversitesi, Sağlık Bilimleri Fakültesi, Hemşirelik Bölümü, Kars, Türkiye \\ ORCID ID:orcid.org/: 0000-0001-7929-8687 \\ ${ }^{2}$ Karabük Üniversitesi, Tıp Fakültesi, Histoloji ve Embriyoloji ABD, Karabük, Türkiye \\ ORCID ID:orcid.org/0000-0002-0065-3656
}

*Sorumlu Yazar e mail: ngey58@hotmail.com

Geliş Tarihi: 04.05 .2020

Kabul Tarihi: 21.09 .2020

Atıf/Citation: Gey, N., Ersan Y. "Deltamethrin'in Carassius gibelio (Bloch, 1782)'nun Solungaç, Karaciğer ve Bağırsak Dokuları Üzerine Histopatolojik Etkilerinin Araştırılması”, Haliç Üniversitesi Fen Bilimleri Dergisi 2020, 3/2: 189-210.

Araştırma Makalesi/ Research Article

\section{Özet}

Bu çalışma, Deltamethrin uygulanan Carassius gibelio türü balıkların solungaç, karaciğer ve bağırsak dokuları üzerine histopatolojik etkilerini incelenmek amacı ile yapıldı. Araştırmada 60 adet balık, her grupta 12 balık bulunan, 5 gruba ayrıldı. $\mathrm{Bu}$ gruplardan biri kontrol, diğer dördü deney grubu olarak oluşturuldu. Kontrol grubu dışında, deney gruplarındaki balıklar deltametrinin; 0.48, 0.64, 0.80 ve $0.96 \mathrm{mg} /$ L'lik konsantrasyonlarının etkisinde 96 saat bırakıldı. Deney sonunda sakrifiye edilen balıklardan alınan doku örneklerinin tespit ve takip işlemlerinden sonra kesitleri alındı ve bu kesitler Hematoksilen+Eozin $(\mathrm{H}+\mathrm{E})$ ile boyanarak histopatolojik değişiklikler incelendi. Deney gruplarındaki balıklarda; solungaç epitel hücrelerinde hipertrofi, epitelin lameller ayrılması ve mukus hücre hipertrofisi gözlendi. Karaciğerde kistik yapılar, vena centralislerde düzensizlikler, venlerin, hücrelerin ve diğer elemanların birbirinden ayrılamadığı görüldü. Bağırsaklarda ise lezyonlar, mukus hücre proliferasyonu, ölü villus epiteli ve epitel dejenerasyonu saptandı. Deltamethrin'in Carassius gibelio ’nun solungaç, karaciğer ve bağırsak dokuları üzerinde dejeneratif etkilerinin olduğu bulundu. Sonuç olarak Deltamethrin, insan sağllğ 1 ve çevre için çok toksik insektisitlerden biridir. Bu zehirli maddenin kontaminasyonundan sucul ekosistemleri korumak için gerekli önlemler alınmalıdır.

Anahtar Kelimeler: Deltamethrin, Histopatoloji, Carassius gibelio 


\title{
Investigation of Histopathological Effects of Deltamethrin on Gills, Liver and Intestinal Tissues of Carassius gibelio (Bloch, 1782)
}

\begin{abstract}
This study was carried out to investigate the histopathological effects of Deltamethrin on gills, liver and intestinal tissues of Carassius gibelio species. 60 fishes in this research were divided into 5 groups composed by twelve fishes in each group. One of these groups was created as a control group and the other four as experimental groups. Except for the control group, the experimental groups were exposed to the Deltamethrin at the concentrations of $0.48,0.64,0.80$ and $0.96 \mathrm{mg} / \mathrm{L}$. for 96 hours. At the end of the experiment, tissue samples taken from sacrified fish were sectioned after the processes of detection and observation, and the histopathological changes were examined on these samples by staining them with Hematoxylin+Eo$\sin (\mathrm{H}+\mathrm{E})$. Hypertrophy in gills epithelial tissues, lamella separation of the epithelium and hypertrophy of mucous cells were observed in the control group fishes. Necrosis, vacuolar degeneration and nuclear hypertrophy were seen in liver. Lesions, mucous cell proliferation, death of the villus epithelium and epithelial degeneration were observed in the intestines. Deltamethrin's degenerative effects were found on Carassius gibelio's gill, liver and intestinal tissues. As a result, Deltamethrin is one of the most toxic insecticides for human health and the environment. Necessary measures should be taken to protect aquatic ecosystems from contamination by this toxic substance.
\end{abstract}

Key Words: Deltamethrin, Histopathology, Carassius gibelio.

\section{Giriş}

Çağımızda dünya nüfusu hızla çoğalmaya devam etmektedir. Bu çoğalma besin üretiminden daha fazla olduğu için açlik sorununun ortaya çıkmasına neden olmaktadır. Günümüzde bu sorunun çözüm yöntemlerinin en önemlilerinden biri tarımsal etkinliklerde verimi artırmaktır. Ancak tarımda verimliliğin artışı birçok etmene bağlıdır. Bunlardan biri de çeşitli zararlılara karşı kimyasal savaştır. Bu savaşta kullanılan toksik etkili pestisit denilen tarımsal ilaçlar, hem kısa zamanda etkin hem de ekonomik ve kullanımı kolay olması nedeniyle büyük önem 
kazanmıştır. Çünkü pestisitlerin hedef organizmadaki toksik etkisi daha çoktur. Üstelik pestisitler tarımsal etkinliklerde zararlılara karşı yapılan bilinçsizce, yaygın ve yoğun ilaçlamalarla, yağmur suları, drenaj suları ve sulama sularına karışarak toprağı, yeraltı sularını, gölleri, akarsuları ve denizleri kirletmektedir [1, 2]. Ayrıca bu toksik maddeler sucul ekosistemdeki algler, midyeler, balıklar ve memeliler gibi canlılara zarar vererek ölmelerine neden olmaktadır. Üstelik gıda zinciri yoluyla insan sağlığını da olumsuz yönde etkilemektedirler [3, 4].

Dünyada toplam pestisit üretimi yıllık 3 milyon ton kadardır. $\mathrm{Bu}$ miktar pestisitin \%29'luk bölümünü insektisitler oluşturmaktadır. Türkiye'de 2017 y1lında kullanılan toplam pestisit miktarı 54.000 ton'a yükselmiştir. Bu miktar pestisitler içinde fungusitler \%44'lük bir payla biririnci sırayı, \%22.8'lik oranla insektisitler ikinci sırayı almıştır [5]. Yapılan araştırmalarla pestisitlerin gelişmiş ülkelerde kullanımının giderek azamasına karşın, az gelişmiş ve gelişmekte olan ülkelerde daha çok kullanıldığı ortaya konmuştur [6].

Pestisitler içinde yoğun ve yaygin olarak kullanılan, çevre ve insan sağlığı açısından önemli risk taşıyan, sinek öldürücü etkisi yüksek, piretroit grubu insektisitlerden Deltamethrindir [7]. Sentetik kimyasal madde olan bu insektisit, memeliler ve kuşlar için genellikle riskli olmamasına karşın, sinekler, istakoz ve karidesler, zooplankton kommuniteleri ve özellikle balıklar için son derece toksik etkiye sahiptir. Balıklarda bu insektisitin metabolizması ve atılması çok yavaş olduğu için toksik etkisi fazla olmaktadır. Bu özellik balıklarda Deltamethrin'in birikme potansiyelinin yüksek olduğunu göstermektedir. Örneğin, Deltamethrin'in 1991 ve 1995 yıllarının yaz mevsiminde Macaristan'da Balaton Gölü'nde 30 ton yılan balığının (Anguilla anguilla) kitle halinde ölmesiyle ekolojik bir felakete neden olduğu rapor edilmiştir [8].

Balıkların savunmasız hedef organı olan solungaçlar Deltamethrin'i yüksek konsantrasyonda absorbe etmektedirler. $\mathrm{Bu}$ insektisit öncelikle toksik etkisini sinir, solunum ve hematolojik sistemler üzerinde göstermektedir [9]. Canlının en önemli yaşamsal 
fonksiyonlarını yerine getiren bu sistemlerde yoğun ve yaygın olarak kullanılan Deltamethrin'in toksik etkisi yapılan araştırmalarla gösterilmektedir $[10,11]$.

Bu çalışmada Deltamethrin'in Carassius gibelio'nun solungaç, karaciğer ve bağırsak dokuları üzerine histopatolojik etkilerinin incelenmesi amaçlanmıştır.

\section{Materyal ve Metot}

Çalışma 2015 yılının Sonbahar aylarında Kafkas Üniversitesi Fen Edebiyat Fakültesi Genel Zooloji Laboratuvarında yürütüldü. Deney için Çıldır Gölü'nden (Kars-Ardahan/Türkiye) yakalanan Carassius gibelio balıkları kullanıldı. Araştırma esnasında balıklar ticari yemle beslendi. Çalışmada Deltamethrin insektisiti kullanıldı. Bu insektisitin ticari adı dentist 25 EC (Emülsiyon Konsantre) olup litrede 25 gr Deltamethrin içermektedir.

Çıldır Gölü’nden yakalanan Carassius gibelio balıkları canlı halde laboratuvara getirilerek 200 litrelik tanklara yerleştirildi. Deneylere başlamadan önce tankların içi yıkanarak, temizlendi. Deney için kullanılan 60 adet balığın cinsiyet ayrımı gözetilmeksizin yaşları $1^{+}$, ortalama boy ve ağırlık değerleri $22.43 \pm 1.66(20-25) \mathrm{cm}$ ve $159.63 \pm 12.78$ (130-180) gr olarak hesapland1. Gece ve gündüz periyodunun 12/12 olması sağlandı.

Çalışma süresince deneyde kulanılan suyun kimyasal özelliklerinden pH 8.0-8.2; sıcaklığ 1 ise $17.5-18.0{ }^{\circ} \mathrm{C}$ arasında ölçüldü.

Tanklara, kg balığa $0,7 \mathrm{~L} / \mathrm{dk}$.' lık su girişi sağlandı ve bu suya hava motoru ile deney süresince oksijen verilerek çözünmüş oksijen konsantrasyonu, 6.4-8.6 mg/L arasinda bulundu.

İncelemede kullanılan 60 adet balık, her grupta 12'şer adet olmak üzere 5 gruba ayrıldı. Denemede kontrol grubu olarak balıklar 0.00 konsantrasyonda çeşme suyu bulunan tanka yerleştirildi. Deney grupları için yapılan ön çalışmada $1,2,3$ ve 4 . gruptaki balıklar, sırasıyla 0.48, 0.64, 0.80, $0.96 \mathrm{mg} / \mathrm{L}$ 'lik Deltamethrin konsantrasyonlarında, 96 
saat bırakıldı ve bu zaman aralığında konsantrasyon artışlarının balıklar üzerindeki etkisi gözlendi. Ayni uygulama deney gruplarında tekrarland1.

Deney süresi sonunda tanklardaki balıkların solungaç, karaciğer ve bağırsaklarından doku örnekleri alındı. Bu örnekler \% 10'luk nötral formaldehit solüsyonunda 24 saat tespit edildi.

Farklı dokular parafin içine gömüldü, 5-6 $\mu$ kalınlığında kesitler alındı. Rutin histolojik metotlarla preparatlar hazırlanarak Hematoksilen+Eozin $(\mathrm{H}+\mathrm{E})$ boyama metoduyla boyanıp [12] 1şık mikroskobunda (Olympus PM 10 A) fotografları çekildi ve değerlendirildi. Bu araştırma Kafkas Üniversitesi Hayvan Deneylerı Yerel Etik Kurulu'ndan 2014-035 kodlu etik kurul onayı ile yapıldı.

\section{Bulgular}

Deltamethrin'in Carassius gibelio balıklarının solungaç, karaciğer ve bağırsak dokuları üzerindeki etkilerinin histopatolojik incelenmesi sonucu elde edilen bulgular Şekil 1-15'de gösterildi.

\subsection{Solungaç}

\subsubsection{Kontrol Grubu}

Kontrol grubuna ait kesitte solungacı oluşturan primer ve sekonder lameller ve hücreler net bir şekilde izlenmektedir (Şekil 1). 


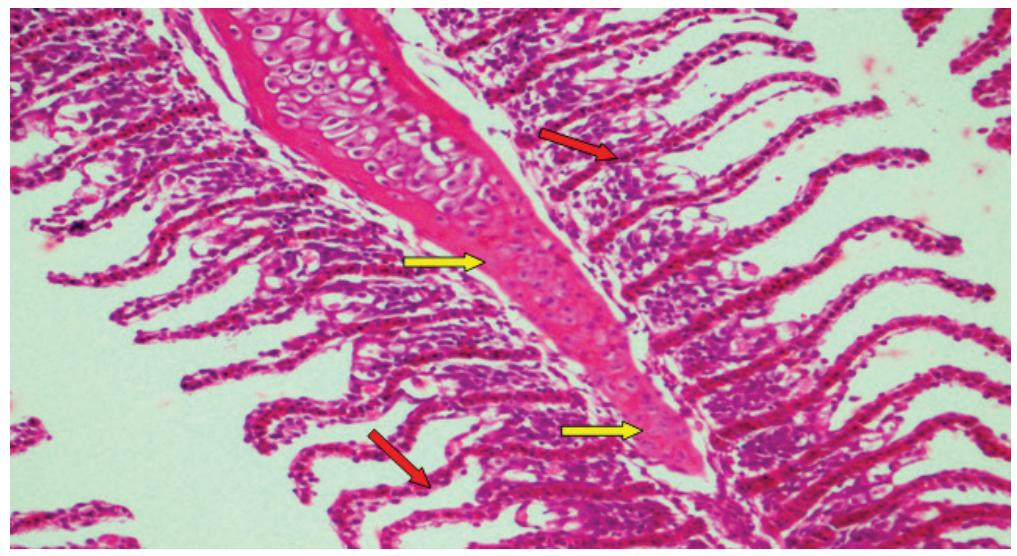

Şekil 1. Carassius gibelio'nun Kontrol Grubu Solungaç Dokusu $(\mathrm{H}+\mathrm{E}, \mathrm{X} 100)$

\subsubsection{Deneme Grupları}

1. grupta solungacı oluşturan hyalin kıkırdak, bazı kısımlarda kıkırdağın perikondriumu içerisinde yırtılıp kaybolmaya başlamış, bazı k1sımlarda ise k1kırdak (sarı ok) tamamen dejenere bir görünümdedir. Ayrıca primer ve sekonder lamellarda (kırmızı ok) yer yer bozulmalar, yırtılmalar ve nekrozlar görülmektedir (Şekil 2).

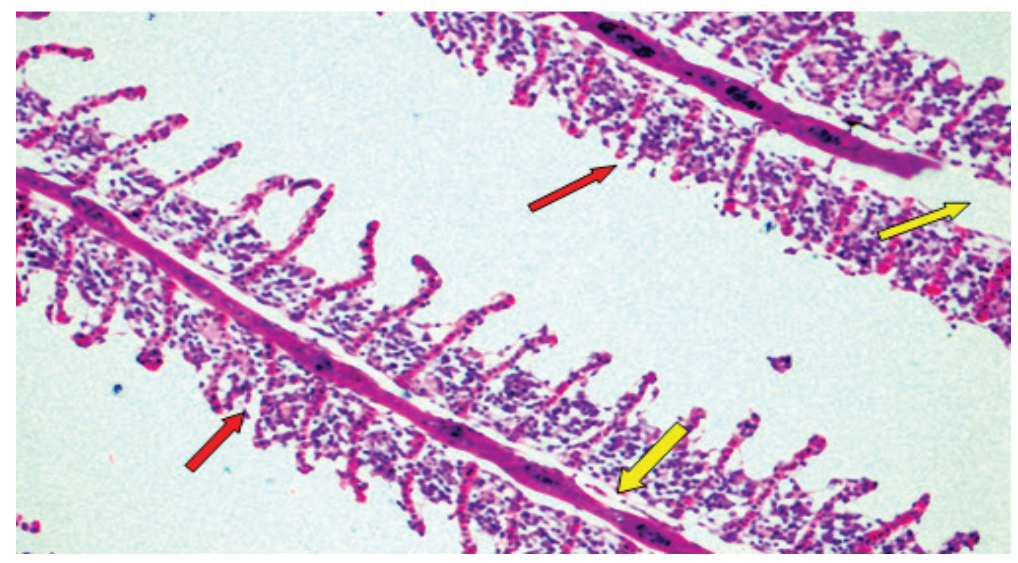

Şekil 2. Deltamethrin Uygulanan 1.Grup $0.48 \mathrm{mg} / \mathrm{L}$ Solungaç Dokusu $(\mathrm{H}+\mathrm{E}, \mathrm{X} 100)$ 
2. gruba ait kesitte hiyalin kıkırdak hücreleri (sarı ok) yoğun dejenerasyon göstermektedir. Ayrıca solungacı oluşturan yapılardaki bozulmalar dikkat çekerken, primer ve sekonder lamellarde (beyaz ok) kayıp ve hücre infiltrasyonları gözlenmektedir (Şekil 3).

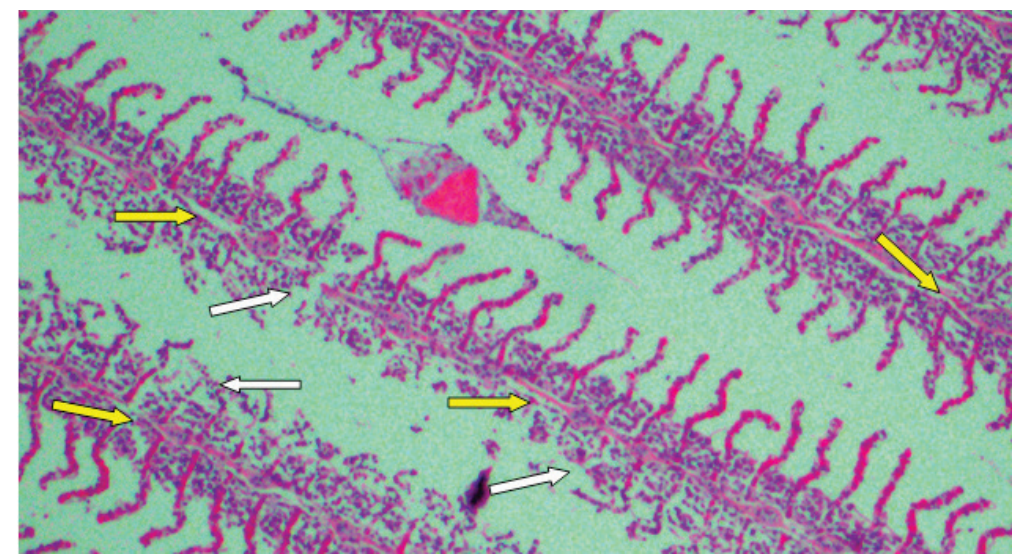

Şekil 3. Deltamethrin Uygulanan 2.Grup $0.64 \mathrm{mg} / \mathrm{L}$ Solungaç Dokusu $(\mathrm{H}+\mathrm{E}, \mathrm{X} 100)$

3. grubun kesitinde solungaça benzer bir yapının ortadan kalktığı, solungacı oluşturan primer ve sekonder lamellalar (kırmızı ok) bozulmuş ve hyalin kıkırdağ 1 oluşturan kondrositler erimiş gibi görülmektedir. Bazı kısımlarda kıkırdağın perikondriumu (sarı ok) içerisinde yırtılıp kaybolmaya başlamış, bazı kısımlarda ise kıkırdak tamamen dejenere (beyaz ok) bir görünümdedir (Şekil 4). 


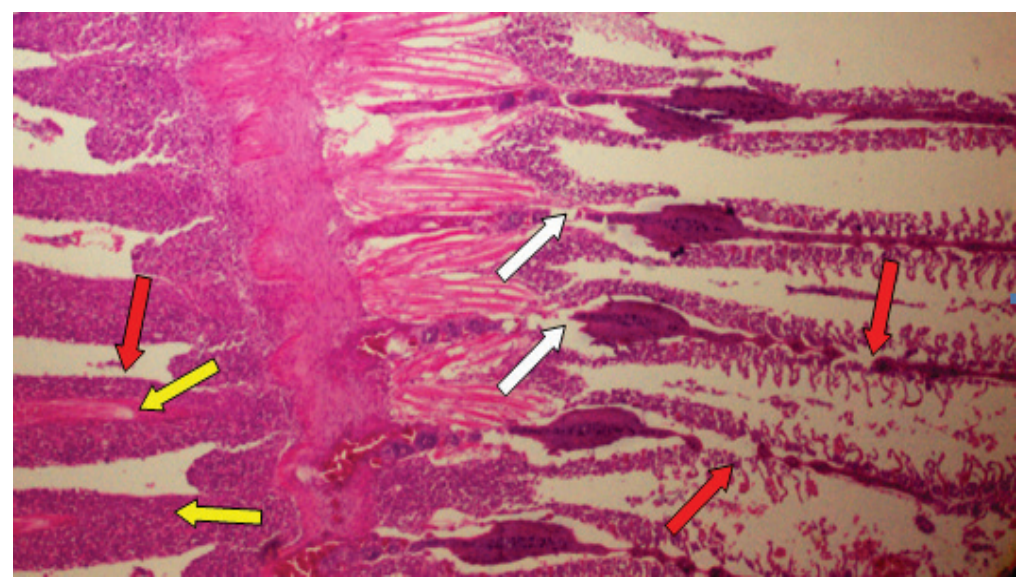

Şekil 4. Deltamethrin Uygulanan 3.Grup $0.80 \mathrm{mg} / \mathrm{L}$ Solungaç Dokusu $(\mathrm{H}+\mathrm{E}, \mathrm{X} 100)$

Deneyde en yüksek konsantrasyonu içeren 4. grup diğerlerine k1yasla birçok alanda kan ve lenfositik (kırmızı ok) yapıların diffuz dağılımından ibaretti. Kıkırdak dokunun (sarı ok) tahrip oluşu net bir şekilde gözlenmektedir. Genel olarak lameller yapılar kaybolmuş, solungaç lamellerini oluşturan epitele ait hücreler (beyaz ok) ise az çok seçilebilmektedir (Şekil 5).

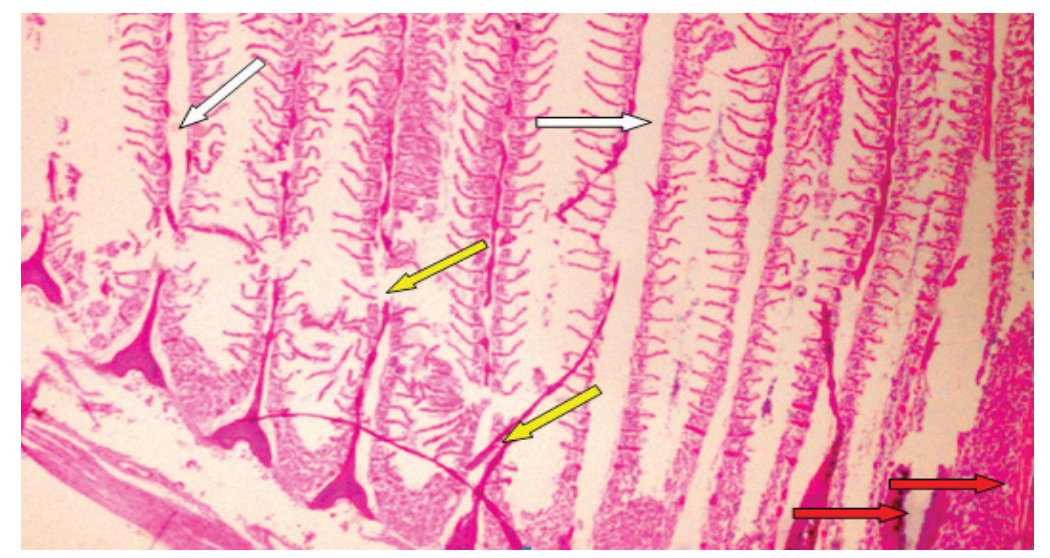

Şekil 5. Deltamethrin Uygulanan 4.Grup $0.96 \mathrm{mg} / \mathrm{L}$ Solungaç Dokusu $(\mathrm{H}+\mathrm{E}, \mathrm{X} 100)$ 


\subsection{Karaciğer}

\subsubsection{Kontrol Grubu}

Karaciğer kontrol grubu dokusunda vena centralis (kırmızı ok) ve yer yer sinusoidlerin (sarı ok) içinde yerleşmiş eritrositler ve etrafında karaciğer hücreleri gayet güzel ayırt edilebilmektedir (Şekil 6).

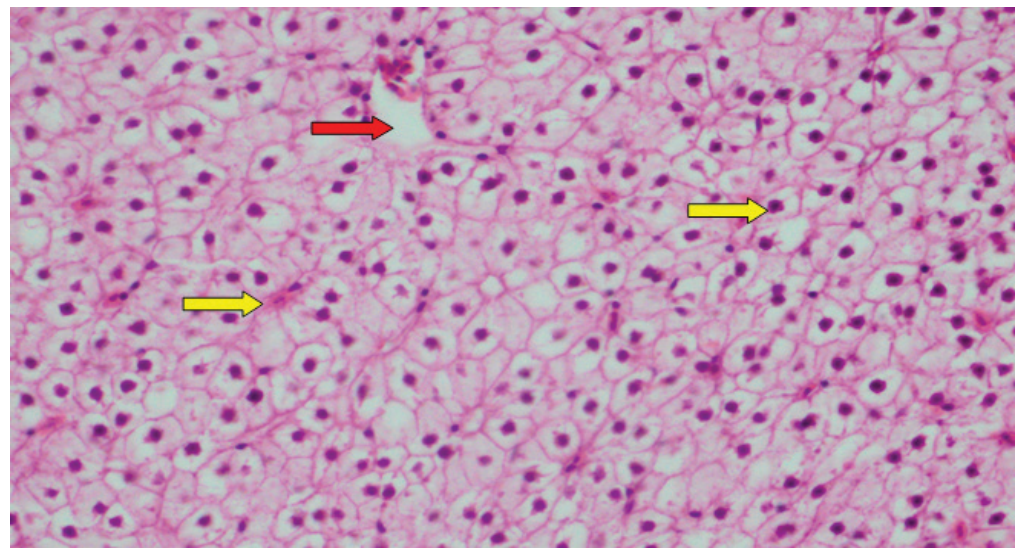

Şekil 6. Carassius gibelio'nun Kontrol Grubu Karaciğer Dokusu (H+E, $\mathrm{X} 100)$

\subsubsection{Deneme Grupları}

1. gruba ait karaciğer kesitinde hepatositlerin yer yer s1k1 s1k1 bir araya gelişi yer yer ise dağınık olarak görünümleri dikkat çekmektedir. Yine hepatik hücrelerin sitoplazması (kırmızı ok) içi boş odacıklar halinde ve çekirdeklerinin yer yer gözlenemediği bir durum mevcuttur. Vena centralis (sarı ok) ve içindeki kan elemanları kolaylıkla izlenmektedir (Şekil 7). 


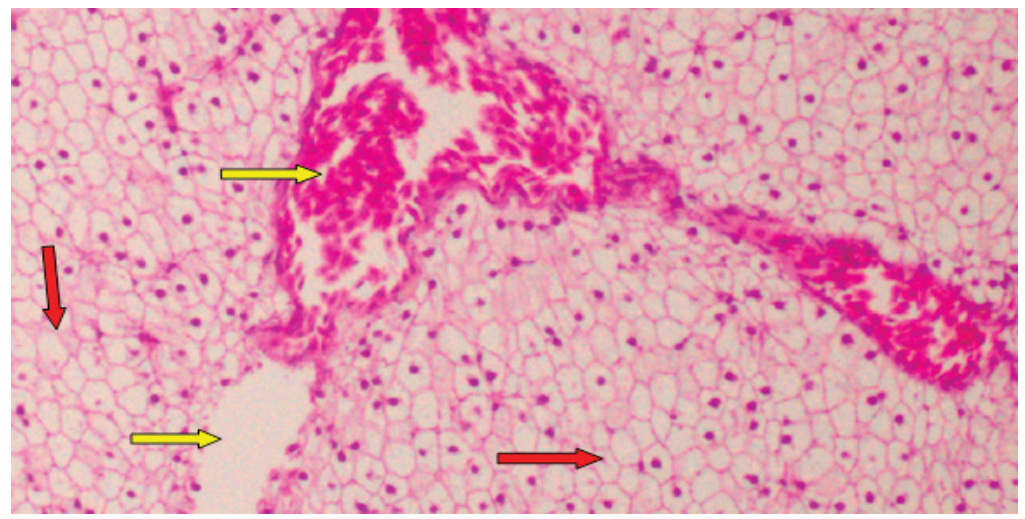

Şekil 7. Deltamethrin Uygulanan 1.Grup $0.48 \mathrm{mg} / \mathrm{L}$ Karaciğer Dokusu $(\mathrm{H}+\mathrm{E}, \mathrm{X} 100)$

2. gruba ait karaciğer kesitinde hepatik hücre kordonlarının ve hücrelerin (sarı ok) akmaya başladığı gibi bir görüntü hakim vaziyettedir. Ayrıca dokuda vena centralislerin (kırmızı ok) düzensizlikleri, sinuzoidler ve etrafında çok fazla ayrıntı vermeyen hepatositler görülmektedir (Şekil 8).

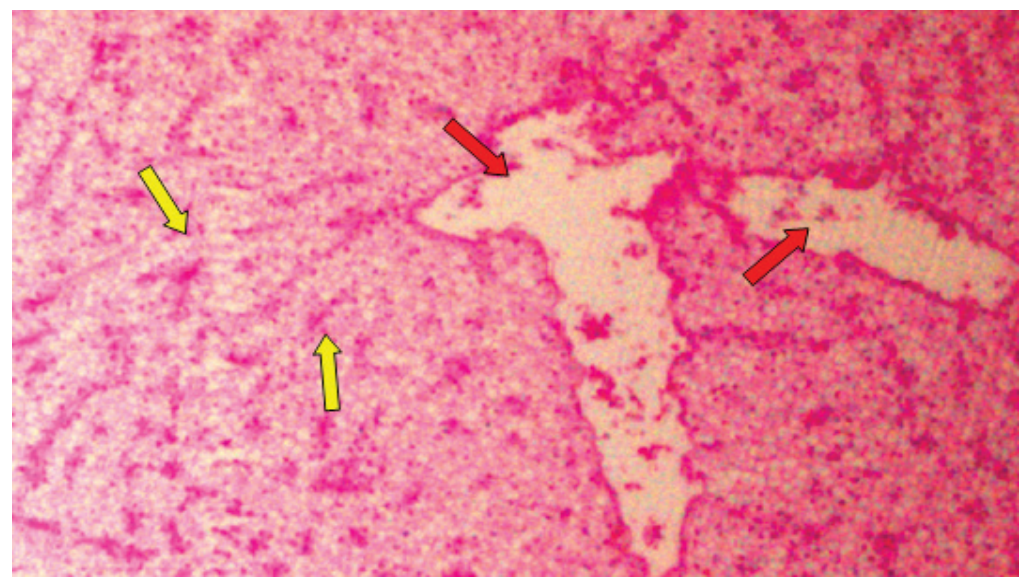

Şekil 8. Deltamethrin Uygulanan 2.Grup $0.64 \mathrm{mg} / \mathrm{L}$ Karaciğer Dokusu $(\mathrm{H}+\mathrm{E}, \mathrm{X} 100)$ 
3. gruba ait kesitte yer yer kanama odakları (kırmızı oklar) ve kistik yapılar (sarı oklar), hepatik hücrelerin sitoplazması içi boş odacıklar halinde ve çekirdeklerinin yer yer gözlenemediği (beyaz oklar), dikkati çekmektedir (Şekil 9).

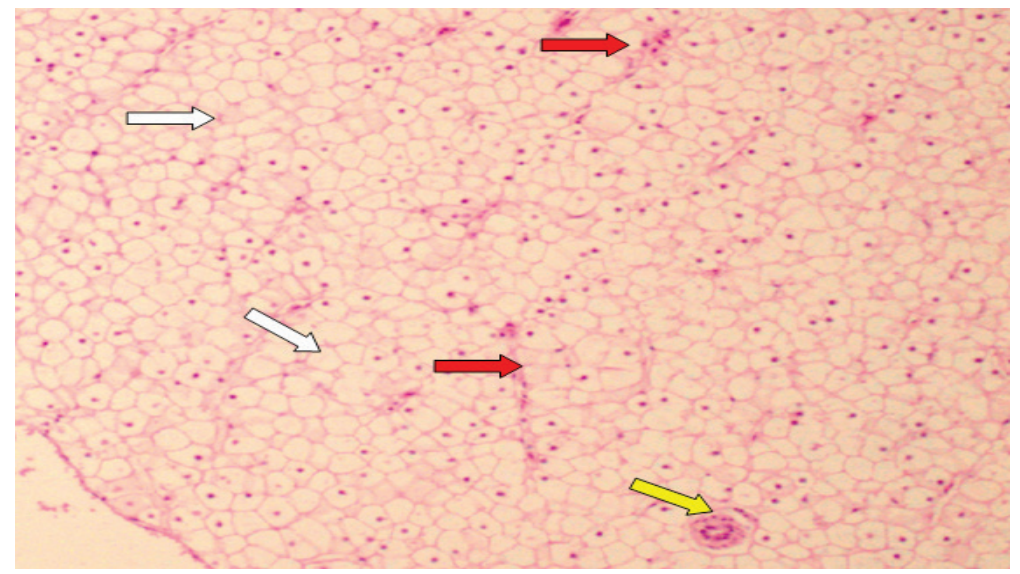

Şekil 9. Deltamethrin Uygulanan 3.Grup $0.80 \mathrm{mg} / \mathrm{L}$ Karaciğer Dokusu $(\mathrm{H}+\mathrm{E}, \mathrm{X} 100)$

4. gruba ait alınan kesitte karaciğer (sarı ok) diyebileceğimiz bir yapı tamamen tahrip olmuşken venlerin, hücrelerin, diğer elemanların birbirinden ayrılamadığı bir durum ilginç bir şekilde dikkat çekmektedir (Şekil 10). 


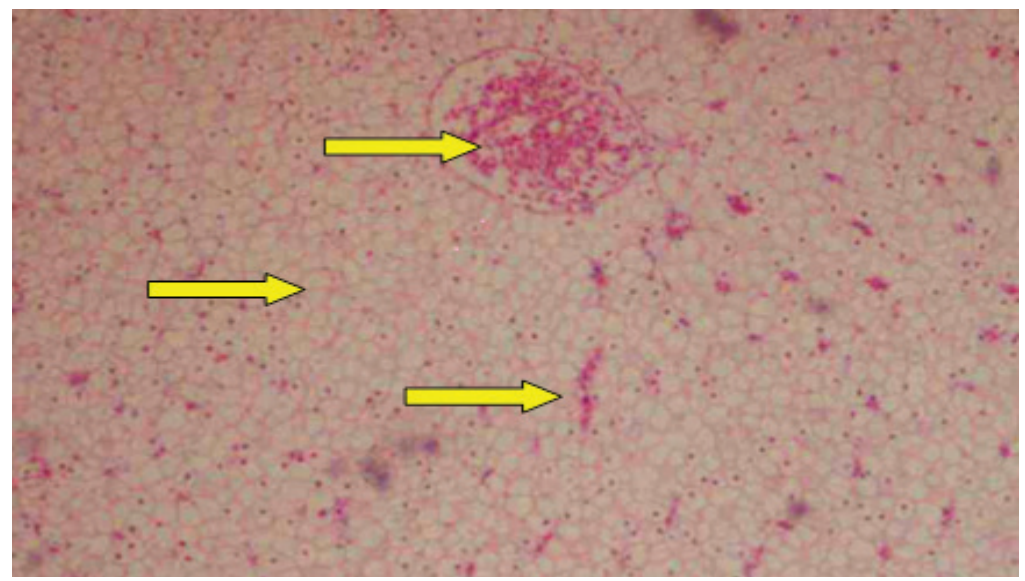

Şekil 10. Deltamethrin Uygulanan 4.Grup $0.96 \mathrm{mg} / \mathrm{L}$ Karaciğer Dokusu $(\mathrm{H}+\mathrm{E}, \mathrm{X} 100)$

\subsection{Bağırsak}

\subsubsection{Kontrol Grubu}

Kontrol grubu bağırsak dokusundan alınan enine kesitlerde villusların arasında lümen (kırmızı ok), bağırsak mukozasının tek katlı prizmatik epiteli ve goblet hücreleri (sarı ok), altında submukoza tabakası (beyaz ok) net bir şekilde izlenmektedir (Şekil 11).

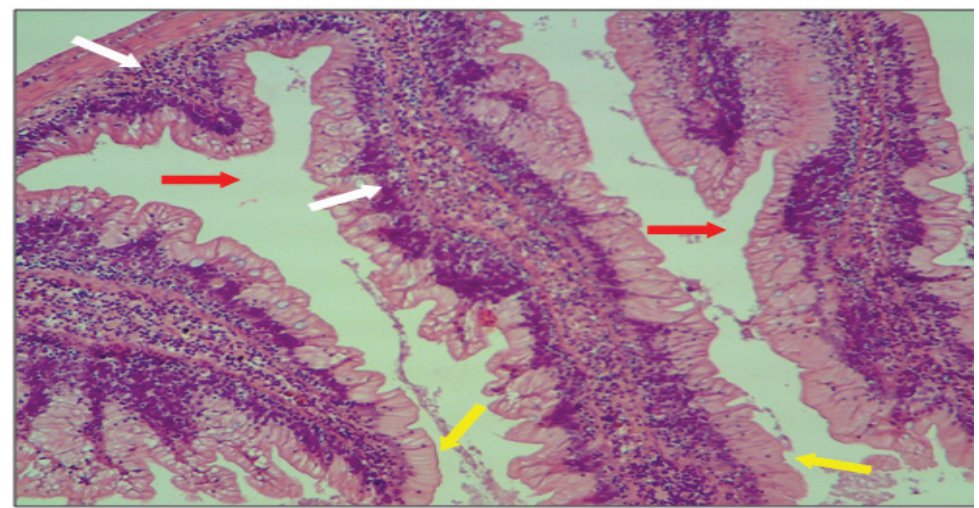

Şekil 11. Carassius gibelio'nun Kontrol Grubu Bağırsak Dokusu $(\mathrm{H}+\mathrm{E}, \mathrm{X} 100)$ 


\subsubsection{Deneme Grupları}

1. grupta bağırsaktan transvers geçmiş kesit düzleminde en önemli veri, lümene doğru villusların üst kısımlarında dejenere olan mukoza (kırmızı ok) izlenmekte; ayrıca mukoza tunika muskularis'deki yırtılma (sarı ok) net olarak görülmektedir (Şekil 12).

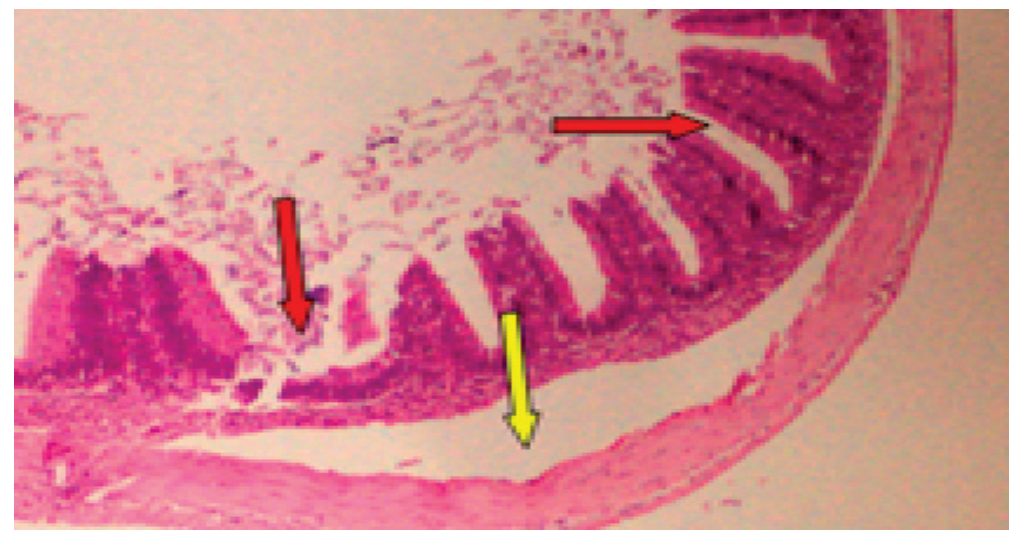

Şekil 12. Deltamethrin Uygulanan 1.Grup $0.48 \mathrm{mg} / \mathrm{L}$ Bağırsak Dokusu $(\mathrm{H}+\mathrm{E}, \mathrm{X} 100)$

2. grupta bazı kısımlarda bağırsak tunica mukozasında (kırmızı ok) dejenerasyonun arttığı izlenirken, ayrıca mukoza tunika muskularis'deki yırtılma ve kopmalar (sarı ok) açıkça görülmektedir (Şekil 13). 


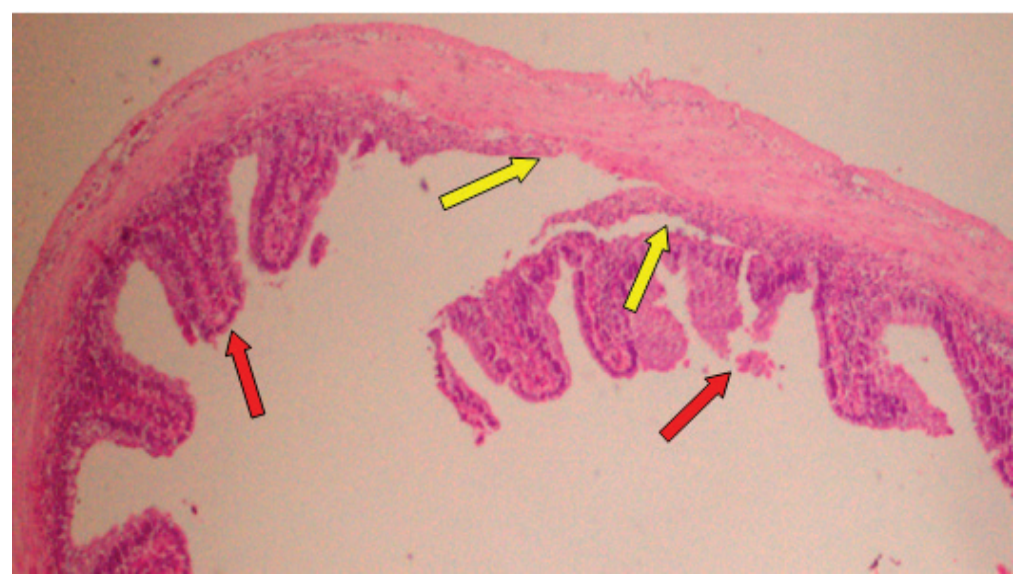

Şekil 13. Deltamethrin Uygulanan 2. Grup $0.64 \mathrm{mg} / \mathrm{L}$ Bağırsak Dokusu $(\mathrm{H}+\mathrm{E}, \mathrm{X} 100)$

3. gruba ait bağırsaktan enine geçmiş kesit düzleminde 1 . ve 2 . gruba göre daha fazla olarak villusların üst kısımlarında dejenere olan mukozaya (kırmızı ok) ait tek katlı prizmatik epitelyum ve aralarındaki goblet hücrelerinin kayboluşu ve altındaki lamina propria'nın apikale doğru akışı net olarak izlenmektedir. Ayrıca tunika muskularis'deki yırtılmış ve yırtılmaya devam eden (sarı ok) alanlar belirgin olarak görülmektedir (Şekil 14).

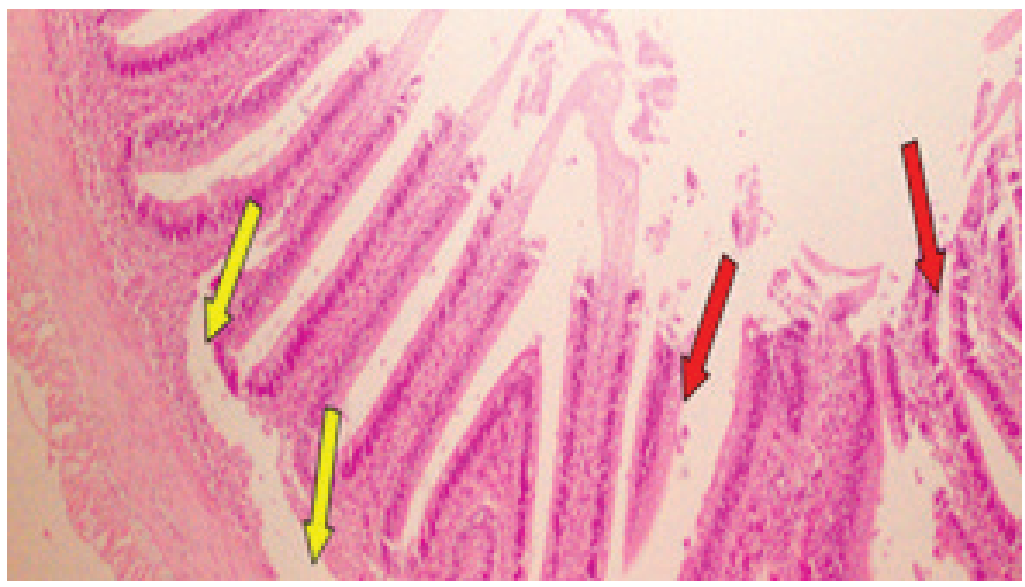

Şekil 14. Deltamethrin uygulanan 3. grup $0.80 \mathrm{mg} / \mathrm{L}$ bağırsak dokusu $(\mathrm{H}+\mathrm{E}, \mathrm{X} 100)$ 
4. gruba ait bağırsak kesitlerinde gözlenen en belirgin özellik villusların (kırmızı ok) ilginç bir şekilde kısalıp kalınlaşması olarak tanımlanabilir. Yer yer villusların tahrip oluşuda (sarı ok) gözlenmektedir. Yine kas dokusu rejenerasyonu (beyaz ok) belirgin olarak izlenmektedir (Şekil 15).

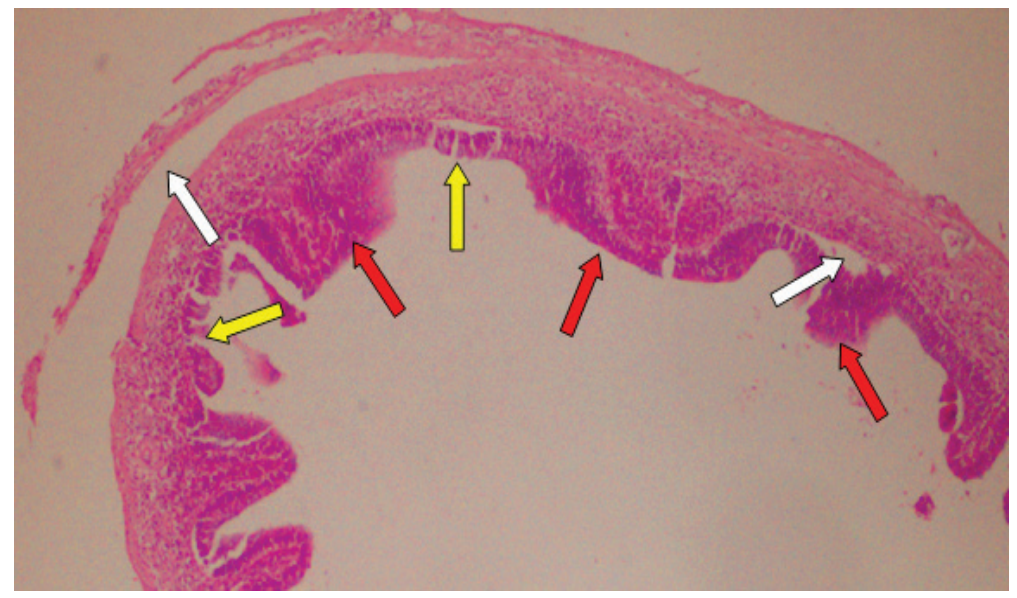

Şekil 15. Deltamethrin uygulanan 4.grup $0.96 \mathrm{mg} / \mathrm{L}$ bağırsak dokusu $(\mathrm{H}+\mathrm{E}$, $\mathrm{X} 100)$

\section{Tartışma}

Balıklarda solungaçlar, gaz değişimini ve ozmoregülasyonu sağlayan, su ortamı ile sürekli temas halinde oldukları için sudaki kirleticilerden en çok etkilenen korumasız organdır. Sucul ortamdaki ağır metaller ve pestisitler gibi çevresel kirleticilerle sürekli temas halinde olan balıkların, bu toksik maddelerin vücutlarına alınması en çok solungaçlar, deri ve sindirim sistemi ile olmaktadır [13].

Karaciğer vücutta metabolik etkinlikler ve toksinlerden arındırma (detoksifikasyon) gibi yaşamsal görevleri olan bir organdır. Balıkların toksik maddelerin etkisinde kalmalarıyla karaciğer dokularında histopatolojik ve metabolik fonksiyonda değişimler bu organın kirlenmede belirleyici bir rolü olduğunu göstermektedir [14]. 
Sindirim sisteminde bağırsaklar, vücuda giren maddelerin sindirilmesi sonucu emilmesini ve kana karışmasını sağlar. Toksik kimyasal maddelerin bağırsak yüzeyinden emilmesi ile oluşan histolojik değişiklikler birçok balık türünde yapılan çalışmalarda $[15,16]$ belirlenmiştir.

Bu çalışmada, deney süresince Deltamethrin'in deneme grubu balıklarının solungaç, karaciğer ve bağırsaklarda oluşturduğu etkileri belirlemek amacıyla yapılan histopatolojik incelemelerde solungaçlarda epitel ve kıkırdak dokularda dejenerasyon, nekrozlar, hücre infiltrasyonları, primer ve sekonder lamellalarda erime, kan ve lenfositik yapılarda diffuz dağılım saptanmıştır.

Literatür incelemelerinde, Tebukonazol'un Cyprinus carpio L., 1758 balıklarının solungaç, karaciğer ve bağırsak histolojisi üzerine etkisiyle ilgili yapılan bir çalışmada solungaç dokusunda; nekroz, sekonder lamel epitellerinde desquamasyon ve hidropik dejenerasyon saptanılmıştır. Karaciğer dokusunda; nekroz, vakuolar ve hidropik dejenerasyonlar gözlenilmiştir. Bağırsak dokusunda ise çoğunlukla nekroz ve dejenerasyonlar olduğu belirtilmiştir (17). Capoeta capoeta (Guldenstaedt, 1773) üzerine Alüminyum klorür uygulanarak yapılan çalışmada solungaç dokuda, konsantrasyon artışıyla orantılı olarak, sekonder lamellerin epitel hücrelerinde dejenerasyon, hipersellülarite ve bazı sekonder lamellerin uçlarında kütleşme olduğu görülmüştür (18). Yayın balığı, Silurus glanis'e uygulanan Endosülfan'dan [19] ve Nil Tilapya, Oreochromis niloticus, balıklarının Glifosat [20] etkisinde kaldıktan sonra solungaçlardaki lamellalarda füzyon rapor edilmiştir. Permethrin uygulanan Salmo gairdneri balıklarının solungaçlarında hiperplazi sonucunda sekonder lamellalarda füzyon gözlendiği bildirilmiştir [21]. Ayrıca solungaçlarda lamellar füzyon; etki yüzeyini daraltarak, sucul ortamdaki kimyasalların dolaşıma geçiş mesafesini artıran fiziksel bir engel olarak değerlendirilebileceği ifade edilmektedir [13]. Bu oluşumla solungaçlarda geniş bir damar ağı olan solunum yüzeylerinin kalınlaşıp, daralmasından kimyasal maddelerin kan dolaşımına geçmesinin bir miktar engellenebileceği öne sürülmektedir. 
Böylece solungaçlarda oluşan hasarın etkisiyle balıkların ozmoregülasyon sisteminin de bozulabileceği rapor edilmiştir [22]. Ayrıca, $\mathrm{Ca}$ rassius gibelio solungaçlarında gözlenen histolojik değişiklikler balıkların kirleticilere karşı doğrudan tepki verdiğini göstermektedir. $\mathrm{Bu}$ tür bilgilerle solungaç dokularında histopatolojik değişikliklerin değerlendirilmesi $[13,22]$ onların iyi bir biyobelirteç olduğunu kanıtlamaktadır. Sunulan çalışmada solungaçlardan elde edilen bulgular daha önce yapılmış çalışmaların $[10,17,21]$ sonuçlarını desteklemektedir.

Mevcut çalışmada Deltamethrin'in etkisinde kalan deney balıklarının karaciğer dokularında sinüzoidler etrafında çok fazla ayrıntı vermeyen hepatositlerin görülmesi, vena centraliste düzensizlikler, yer yer kanama odakları ve kistik yapılar, venlerin, hücrelerin ve diğer elemanların birbirinden ayrılamaması, karaciğerin tamamen tahrip olması gözlenmiştir. Pestisitlerin etkisinde kalan balıklar üzerinde daha önce yapılan histopatolojik çalışmalarda örneğin, Sivrisinek balıkları, Gambusia affinis, üzerine Deltamethrin uygulamasıyla yapılan bir çalışmada; karaciğerde lezyonlar, hepatositlerin hipertrofisi, dolaşım bozuklukları, fokal nekroz, sinüzoidlerde daralma gözlendiği bildirilmiştir [23]. Başka bir çalışmada, Oreochromis niloticus karaciğerinde Deltamethrin uygulamasıyla hipertrofi, vakuoler ve yağ dejenerasyonları, piknotik nukleus, fokal nekroz, çift nukleuslu hücrelerin gözlendiği belirtilmiştir [24].

Çağımızda yoğun endüstriyel ve tarımsal etkinlikler sonucu oluşan atıkların özellikle petsisit ve ağır metaller gibi toksik kimyasal maddelerin sucul sistemlere bırakılması ile oluşan su kirliliğinden etkilenen balıkları histopatolojik yönden inceleyen ekotoksikolojik çalışmalar yapılmakta ve yayınlanmış birçok araştırma raporu da bulunmaktadır. Yukarı Sakarya Havzasında yaşayan Sazan balıkları (Cyprinus carpio) üzerinde histopatolojik yöntem kulanılarak yap1lan bir çalışmada [25] karaciğer dokusunda hipertrofi, konjesyon ile özellikle lobüllerin perifer bölgelerinde mononükleer hücre infiltrasyonu ve nekroz saptanılmıştır. Seyhan Baraj Gölü’nün kirli ve temiz alanlarında yaşayan Cyprinidae familyasına mensup balıklar üzerinde 
histolojik ve biyokimyasal yöntemlerle yapılan saha çalışmasında [26] temiz ve kirli sulardan yakalanan balıkların karaciğer preparatlarının karşılaştırılmasında kirli bölgede yaşayan balıkların karaciğer dokularında mononükleer enflamatuar hücre infiltrasyonu, karaciğerin sinüzoidlere çok yakın bazı bölgelerindeki prolifere hepatositlerde yaygın dejenerasyon, tıkanıklıklar ve ayrıca mikro ve makroveziküler yağ dejenerasyonları gözlemlendiği bildirilmiştir. Mısır'da tarımsal ve evsel kirleticilerin etkisindeki Qarun Gölü'nden yakalanan Tilapia zilli ve Solea vulgaris balıklarında yapılan histopatolojik çalışmada solungaçlarda solungaç epitelinde proliferatif, dejeneratif ve nekrotik değişiklikler; sekonder lamellerde ödem, solungaç filamentlerinin kan damarlarında genişleme ve tıkanıklık, mukoza hücrelerinin çoğalmas1 görülmüştür. Karaciğerde hepatositlede vakuolar dejenerasyon, nekroz ve fibrozun fokal alanları, kan sinüzoidlerinde genişleme ve t1kanıklık ve merkezi damarlarda tromboz oluşumu saptanılmıştır Bağırsakta ise submukoza ve mukoza arasında ödem bulunan dejeneratif ve nekrotik değişiklikler, serozanın kan damarlarında genişleme ve muskularis ve submukozada atrofi olduğu rapor edilmiştir (27). Bu sonuçlar, histopatolojik gözlemlerin kirli alanlar için balık karaciğer metabolizmasının hassas göstergeleri olarak kabul edilebileceğine dair kanıtlar sunmaktadır. Mevcut çalışmada elde edilen histopatolojik veriler daha önce yapılan ve yukarıda örneklenen çalışmaların $(24,26$, 27) sonuçlarıyla benzerlik göstermektedir.

Bağırsaklar toksik kimyasal maddelerin emildiği önemli bir organıdır [28]. Sunulan çalışmanın deneme gruplarındaki balıkların bağırsaklarında genellikle villusların üst kısımlarında dejenere olan mukoza izlenmekte; ayrıca mukoza tunika muskularis'deki yırtılma açıkça görülmektedir. Bağırsak kesitlerinde gözlenen en belirgin özellik villusların kısalıp kalınlaşmasıdır. Balıklarda toksik maddelerin etkisiyle oluşan bağırsak histopatolojisi üzerine birçok araştırma [27, 29, 30] bulunmaktadır. Çıldır Gölü'nden yakalanan Havuz balıklarına uygulanan Cypermethrin'in bağırsakta; infiltrasyon odakları, bağ dokuda yoğunlaşmalar, villuslarda parçalanma ve tek katlı epitelyum 
hücrelerinde y1kılmalar saptanılmıştır [29]. Nasser Gölü'nde (Kalabsha yöresinden) yakalanan Lates niloticus türü balıkların bağırsaklarında; bağırsak lezyonlarının sıklığı, nekrozlu fokal deformasyon, villus mukozal epitel tabakası genişlemesi, vakuolar dejenerasyon veya hiyaline bağlı bağırsak villuslarında dejenerasyon, lenfositik infiltrasyon, ayrışma ve kas demetlerinin azalması gibi histolojik incelemede büyük değişiklikler saptanılmıştır [30].

Deltamethrin'in Carassius gibelio balıklarının solungaç, karaciğer ve bağırsak dokularındaki etkilerinin histopatolojik yöntemle incelenmesi sonucunda elde edilen veriler literatür olarak verilen çalışmaların $[10,23,29]$ sonuçları ile uyumlu oldukları bulunmuştur.

\section{Sonuçlar}

Deltamethrin toksik bir insektisit olmasına karşın, bu maddenin konsantrasyonuna bağlı olarak balıkların; duyarlılık düzeyi, balığın türü, cinsiyeti, metrik özellikleri de balık ölümünü arttırmakta veya azaltmaktadır.

$\mathrm{Bu}$ nedenle çalışmada yapılan histolojik gözlemler, toksik olan Deltametrin'in balıkların solungaç, karaciğer ve bağırsak dokularında histopatolojik değişikliklere neden olduğunu ortaya çıkardı. Mevcut histolojik araştırmaların bulguları, çeşitli dokularda gözlemlenen histopatolojik değişiklerle Deltametrin'in artan konsantrasyonları arasında doğrudan bir ilişki olduğunu göstermektedir. Ayrıca solungaç, karaciğer ve bağırsakta gözlemlenen histopatolojik değişiklikler, Deltametrin'in balıkların ölümüne yol açan ciddi fizyolojik sorunlara da neden olabilir.

Sonuç olarak, elde edilen veriler ekolojik risk değerlendirmesinde yararlıdır. Çünkü bir tarım ülkesi olan Türkiye'de Ardahan ve Kars illerinde kıyısı olan Çıldır Gölü çevresinde hem tarımsal hem de hayvansal etkinliklerde oldukça yoğun, yaygın ve bilinçsizce kullanılan insektisitlerden Deltamethrin'in Carassius gibelio ve dokuları üzerinde yıkıma neden olduğu görülmüştür. Bu nedenle Deltamethrin'in 
kullanıldığı bölgelerle bağlantılı olan sucul ortamların bu insektisitin toksik etkisinden korunması için kullananların bilgili olması gerekir. Diğer yandan toksisitesi oldukça yüksek olan bu insektisitin kullanımının denetim altına alınması gerekir.

Pestisitlerin kullanımını ve etkilerini azaltmak için halk biliçlendirilmelidir. Bunun için, pestisit kulanımı ile ilgili topluma eğitimler verilmeli; özellikle tüketiciler ve uygulayıcılar eğitilmeli; insan ve çevresi için daha az toksik olan pestisitler tercih edilmeli; kalıcı organik kirliliğe neden olan pestisitlerin satışı ve kullanımı konusunda gerekli yasal önlemler alınmalıdır.

\section{Teşekkür}

Bu çalışmada katkıda bulunan Doç. Dr. Hüseyin GEY'e ve emeği geçenlere teşekkür ederim.

\section{Kaynaklar}

[1] Kırıcı, M., Kırıcı, M., Işık, M, Atamanalp, M., İmidacloprid ve Lambda Cyhalothrin'ın Capoeta Capoeta Umbla Böbrek Dokusunda Glikoz 6-Fosfat Dehidrogenaz Enzimi Üzerine in Vitro Etkileri, Türkiye Tarımsal Araştırmalar Dergisi, 2, (2015) 8-14.

[2] Atmaca, E., Pestisitlerin Su Canlıları Üzerine Etkileri, Türkiye Klinikleri Dergisi, 2(2), (2016) 50-57.

[3] Yılayaz, Ö., Parathion Methyl (İnsektisit)'in Capoeta trutta (Heckel, 1843) Üzerindeki Genotoksik Etkisinin Eritrosit Mikronukleus Testi ile Belirlenmesi, Doğu Anadolu Bölgesi Araştırmaları, (2006) 1-5.

[4] Dökmeci, A. H., Şabudak, T., Özbek, A., Ş., Tekirdağ Kıyı Bölgesinden Toplanan Balıklarda Kalıcı Organik Kirleticiler (Kok), Afyon Kocatepe Üniversitesi, Fen ve Mühendislik Bilimleri Dergisi, 19, (2019) 571-579.

[5] https:// csb.gov.tr/tarimilaci-pestisit-kullanimi-i-85834 (Erişim Tarihi: 18.012.2019)

[6] Sarıgül, Z., Bekcan, S., Herbisit Glifosatın Daphnia Magna Üzerine Akut Toksisitesi, Tarım Bilimleri Dergisi, 15(2), (2009) 204-208.

[7] Ünal, G., Gürkan, M.O., İnsektisitler Kimyasal Yapıları, Toksikolojileri ve Ekotoksikolojileri, Ankara Üniversitesi Ziraat Fakültesi Bitki Koruma Bölümü, 159 s., Ankara, (2001). 
[8] Velisek, J., Dobsikova, R., Svobodova, Z., Modra, H., Luskova, V., Effect of Deltamethrin on the Biochemical Profile of Common Carp (Cyprinus carpio L.), Bull. Environ. Contam. Toxicol., 76, (2006) 992-998.

[9] Berköz, M., Yalın, S., Çömelekoğlu, Ü., Mazmancı, B., Mazmanci, M.A., Üyayar, A., Eroğlu, P., Deltamethrin'in Beyinde Oluşturduğu Oksidatif Hasarın Önlenmesinde Funalia trogii'nin Rolü, Mersin Üniv. Sağlık Bilim Dergisi, 3(1), (2010) 1-8.

[10] Yıldırım, M.Z., Karasu, Benli., A.Ç., Selvi, M., Özkul, A., Erkoç, F., Koçak, Ö., Acute Toxicity, Behavioral Changes, and Histopathological Effects of Deltamethrin on Tissues (Gills, Liver, Brain, Spleen, Kidney, Muscle, Skin) of Nile Tilapia (Oreochromis niloticus L.) Fingelings. Environ. Toxicol., 21(6), (2006) 614-20.

[11] Sharma., D.K., Ansari, B.A., Efect of Deltametrin and A Neem Based Pesticide on Some Biochemical Achook on Some Biochemical Parameters in Tissues Liver, Ovary and Muscle of Zebrafish Danio rerio (Cyprinidae), Res.J.Chem.Sci. Vol., 1(4), (2011) 125-134.

[12] Luna, L.G., Manual of Histologic Stainning Methods of the Armed Forces. Institute of Pathology, Mc-Graw-Hill, New York. U.S.A, (1968) 33.

[13] Üreten, M., Üçüncü, İ.S., Dioktil Adipat (DOA)'ın Sparus aurata (Çipura) Karaciğer ve Solungaç Histolojisi Üzerine Etkileri, Ege Su Ürünleri Dergisi, 30(3), (2013) 115-122.

[14] Çapkın, E., Altınok, İ., Endosulfanın Juvenil Gökkuşağı Alabalıkları (Oncorhynchus mykiss) Üzerine Akut Toksik Etkilerinin Belirlenmesi, Ulusal Su Günleri, Trabzon, (2005) 385-90.

[15] Velmurugan, B., Selvanayagam, M., Cengiz, E.İ., Ünlü, E., The Effects of Fenvalerate on Different Tissues of Freshwater Fish Cirrhinus mrigala, J. Environ. Sci. Heal. B, (2007) 157-163.

[16] Ahmadmoradi, E., Rezaie, A. Mousavi, M.S., Histopathological Study of the Kidney, Liver and Intestine Tissues in Goldfish (Carassius auratus) and Angelfish (Pterophyllum sp.) AACL Bioflux, Volume, 5 (4), (2012) 282-288.

[17] Özgür, E., Yılmaz., M., Ersan, Y., Koç, E., Tebukonazol (Fungusit)'un Cyprinus Carpio L., 1758'nun Karaciğer, Solungaç, Böbrek ve Bağırsak Histopatolojisi Üzerine Etkilerinin İncelenmesi, Kafkas Üniversitesi Fen Bilimleri Enstitüsü Dergisi, 11 ( 2), ( 2018) 94-103.

[18] Yılmaz, M., Yanar, S. G., Koç, E., Ersan, Y., Alüminyum Zehirlenmesinin Capoeta Capoeta (Guldenstaedt 1773)'nın Serum Proteinleri ve Solungaç Histopatolojisi Üzerine Etkileri, Caucasian Journal of Science, Journal Home Page: www.cjoscience.com, 5 (2), (2018) 17-26.

[19] Nowak B,. Histological Changes in Gills Induced by Residues of Endosulfan, Aquat. Toxicol., 23, (1992) 65-84. 
[20] Jiraungkoorskul, W., Upatham, E.S., Kruatrachue, M., Sahaphong, S., Vichasri Grams S., Pokethitiyook, P., Biochemical and Histopathological Effects of Glyphosate Herbicide on Nile Tilapia (Oreochromis niloticus), Environ. Toxicol., 18, (2003) 260-267.

[21] Kumaraguru, A.K., Beamish, F.W.H., Ferguson, H.W., Direct and CircuLatory Paths of Permethrin Causing Histopathological Changes in The Gills of Rainbow Trout Salmo gairdneri Richardson, J. Fish. Biol., 20(1), (1982) 87-90.

[22] Üçüncü, İ.S., Önen, Ö., Ergen, G., Üreten Boz E., Seferoğl, K., Gökçe, B., Dioktil Adipat'in (DOA) Labidochromis caeruleus'un Fryer, 1956 (Cichlidae, Teleostei) Solungaç Histolojisi Üzerine Etkileri, Kafkas Univ. Vet. Fak. Dergisi, 16(2), (2010) 343-346.

[23] Cengiz, E.İ., Ünlü, E., Sublethal Effects of Commercial Deltamethrin on the Structure of the Gill, Liver and Gut Tissues of Mosquitofish, Gambusia affinis: A Microscopic Study, Environ. Toxicol. and Phar., 21(3), (2006) 246-253.

[24] Kan, Y., Cengiz ,E., Ugurlu, P., Yanar, M., The Protective Role of Vitamin E on Gill and Liver Tissue Histopathology and Micronucleus Frequencies in Peripheral Erythrocytes of Oreochromis niloticus Exposed to Deltamethrin. Environ. Toxicol. and Phar., 34, (2012) 170-179.

[25] Barlas, N., Yukarı Sakarya Havzasında Yaşayan Sazan Balıklarının (Cyprinus carpio L., 1758) Solungaç, Karaciğer ve Böbrek Dokularının Histopatolojik Olarak İncelenmesi, Tr. J. of Veterinary and Animal Sciences 23 Ek Say1 2, (1999) 277-284.

[26] Gül, Ş., Ergül, B., Yıldız, E., Şahan, A., Doran, F., Pollution correlated modifications of liver antioxidant systems and histopathology of fish (Cyprinidae) living in Seyhan Dam Lake, Turkey, Environ. International, 30, (2004) 605-609.

[27] Mohammed, A.S.F., Histopathological Studies on Tilapia zillii and Solea vulgaris from Lake Qarun, Egypt, World Journal of Fish and Marine Sciences 1(1), (2009) 29-39

[28] Uçar, A., Atamanalp, M., Balıklarda Toksikopatolojik Lezyonlar I. Atatürk Üniv. Ziraat Fak. Dergisi, 39(2), (2008) 255-261.

[29] Özden, Z., Çıldır Gölünde Avlanan Havuz Balığı (Carassius gibelio Bloch, 1782) Üzerine Cypermethrin'in Etkilerinin Histopatolojik, Genotoksik, Elektroforetik ve Biyokimyasal Yöntemlerle Araştırılması. Kafkas Üniversitesi, Fen Bilimleri Enstitüsü, Biyoloji Anabilim Dalı, Yüksek Lisans Tezi, (2016).

[30] Seham, A.İ., Gaber, H.S., Ghamdi, F.A., Midhat, K.A., Histopathogical Alterations in Fish Organs as Potential and Direct Biomarkers of Pollution, The Egyptian Society for Environmental Sciences Catrina, 9(1), (2014) 25 -31. 